\title{
MENINGKATKAN KETERAMPILAN BERPIKIR SISWA DENGAN MODEL LEARNING CYCLE DALAM PEMBELAJARAN FISIKA DI SMA JAKARTA
}

\author{
NINTA SRI ULINA \\ nintaulina@gmail.com \\ Program Studi Teknik Industri \\ Fakultas Teknik, Matematika dan Ilmu Pengetahuan AlamUniversitas Indraprasta PGRI \\ Jl. Nangka No.58 Tanjung Barat, Jakarta Selatan, Indonesia
}

\begin{abstract}
Abstrak. Penelitian ini bertujuan untuk meningkatkan keterampilan berpikir siswa dengan model Learning Cycledalam pembelajaran Fisika. Penelitian ini dilakukan pada bulan Februari sampai dengan Maret 2011 di SMAN 21 Jakarta. Subjek penelitian ini adalah siswa kelas X-3 yang berjumlah 36 orang. Metode yang digunakan dalam penelitian ini adalah Penelitian Tindakan Kelas (Classroom Action Research) dimana hasil analisis dari suatu pembelajaran direfleksikan pada pembelajaran berikutnya. Penelitian ini terdiri dari tiga siklus, yaitu siklus I, siklus II, dan siklus III, yang pada setiap siklusnya terdiri dari 4 sampai 6 pertemuan. Siklus pertama membahas suhu dan pemuaian, siklus kedua membahas Kalor dan perubahan wujud, dan siklus ketiga membahas perpindahan kalor. Aspek yang diukur pada penelitian ini adalah keterampilan berpikir siswa dengan indikator metakognitif, inferensi, dekontekstualisasi, dan kombinasi dan sintesis. Pada siklus I rata-rata pencapaian jumlah siswa yang melakukan aktivitas pembelajaran dengan baik sebesar $45,88 \%$. Hasil rata-rata keterampilan berpikir siswa sebesar 57,9\%. Pada siklus II hasil rata-rata pencapaian jumlah siswa yang melakukan aktivitas pembelajaran mengalami peningkatan yaitu sebesar $67,18 \%$, begitu pula dengan rata-rata keterampilan berpikir siswa sebesar $77,2 \%$. Pada siklus III rata-rata siswa yang melakukan aktivitas pembelajaran dengan baik sebesar $88,86 \%$ dan hasil ratarata keterampilan berpikir siswa mencapai 93,2\%. Hasil penelitian ini menunjukkan bahwa model learning cycle dapat meningkatkan keterampilan berpikir siswa dan aktivitas belajar siswa.
\end{abstract}

Kata Kunci : Model, Pembelajaran, Learning Cycle, Keterampilan berpikir, Fisika.

\section{PENDAHULUAN}

Keterampilan berpikir dapat didefinisikan sebagai proses kognitif yang dibagi ke dalam langkah-langkah nyata yang kemudian digunakan sebagai pedoman berpikir. Keterampilan berpikir tingkat tinggi adalah suatu desain kreatif untuk membangun keterampilan berpikir dari masalah yang didapatkan siswa ketika duduk di kelas 4-7. "HOTS is a creative program designes to build the thinking skills of educationally disadvantaged students in grade 4-7." (Pregrew, 1996). Keterampilan berpikir digunakan untuk menyelesaikan suatu masalah yang harus dipecahkan oleh siswa dalam proses pembelajaran (dalam hal ini, proses belajar mengajar fisika).

Salah satu kecakapan hidup ( life skill) yang perlu dikembangkan melalui proses pendidikan adalah ketrampilan berpikir (Depdiknas, 2003). Keterampilan berpikir peserta didik diukur menurut hirarki (tingkat kognitif) yang disampaikan oleh Bloom (1952), mencakup: Knowledge, acquisition, Comprehension,Application,Analysis,Synthesis, and Evaluation.

Learning Cycle merupakan salah satu model pembelajaran dengan pendekatan kontruktivis. Model pembelajaran siklus pertama kali diperkenalkan pertama kali oleh 
Robert Karplus dalam Science Curriculum Improvement Study/SCIS (Trowbridge \& Bybee, 1996).

Terampil berpikir adalah salah satu cara agar siswa dapat menjawab berbagai permasalahan fisika dalam metode yang ilmiah. Oleh karena itu, melalui model pembelajaran Learning Cycle diharapkan siswa semakin trampil berpikir dalam menyelesaikan masalah melalui pembelajaran fisika.

\section{METODE}

Penelitian dilakukan di SMA Negeri 21 Jakarta pada bulan Februari sampai dengan Maret 2011. Metode penelitian adalah Penelitian Tindakan Kelas mengacu pada pendapat Kurt Lewin dengan tahapan: (1) perencanaan (planning), (2) tindakan (acting), (3) pengamatan (observing), dan (4) refleksi (reflecting). (Supriyadi, 2007) Desain Penelitian dimodifikasi dari pendapat Lewin, disajikan pada gambar 1.

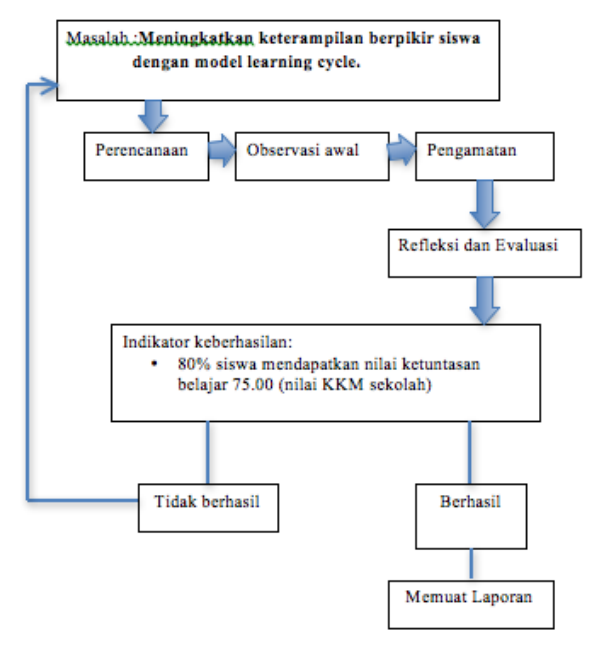

Gambar 1. Skema Penelitian

Data yang terkumpul setiap siklusnya ialah data hasil obervasi atau pengamatan, dan keterampilan berpikirsiswa yang diperoleh dari hasil test uraian terbatas. Data keterampilan berpikir siswa diolah secara kualitatif dengan indikator keterampilan berpikir.

Pemberian Skor terhadap jawaban siswa mengacu pada pendapat Sugiyono (1996):

$$
T K=\frac{\Sigma S}{S \max } \times 100 \%
$$

Dengan:

TK: persentase tingkat keberhasilan belajar siswa (\%)

$\Sigma S \quad$ :jumlah skor yang diperoleh

Smax: skor maksimum (ideal)

Tingkat keberhasilannya akan dibagi menjadi lima kategori skala dengan klasifikasi sebagai berikut: 
Tabel 1. Tingkat Keberhasilan Keterampilan Berpikir Siswa

\begin{tabular}{|c|c|}
\hline Persentase & Keterangan \\
\hline $80 \%$ atau lebih & Sangat tinggi \\
\hline $60 \%-79 \%$ & Tinggi \\
\hline $40 \%-59 \%$ & Sedang \\
\hline $20 \%-39 \%$ & Rendah \\
\hline $0 \%-19 \%$ & Sangat rendah \\
\hline
\end{tabular}

Sumber:Arikunto, 2003:215

Berdasarkan tabel di atas, diharapkan keterampilan berpikirsiswa adalah $80 \%$ dan nilai hasil tes siswa berada di atas Kriteria Ketuntasan Minimal (KKM) yaitu 75.

\section{Tahapan-tahapan dalam Pembelajaran}

Tahapan- tahapan dalam Learning Cycle terdiri dari 5 tahap, yaitu a) tahap pembangkitan minat (engagement), b) tahap eksplorasi (exploration), c) tahap penjelasan (explanation), d) tahap elaborasi (elaboration), dan e)tahap evaluasi (evaluation). (Lorsbach, 2002)

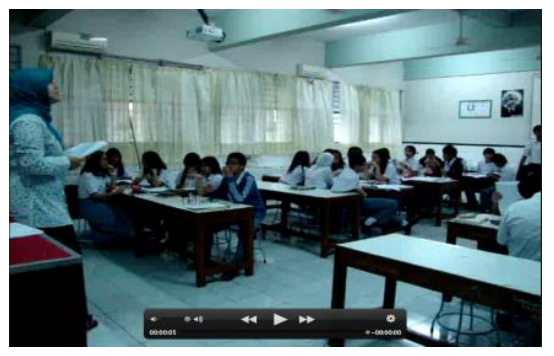

Gambar 2. Tahap Engagement

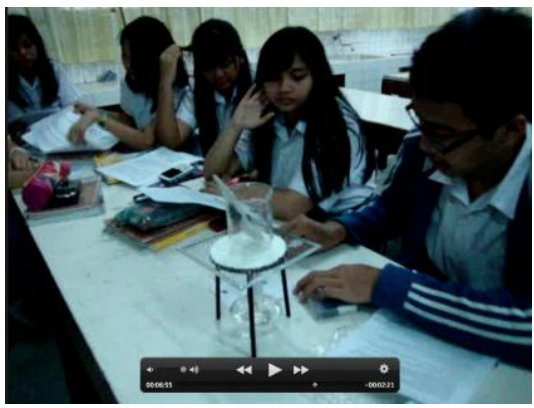

Gambar 3. Tahap Eksplorasi

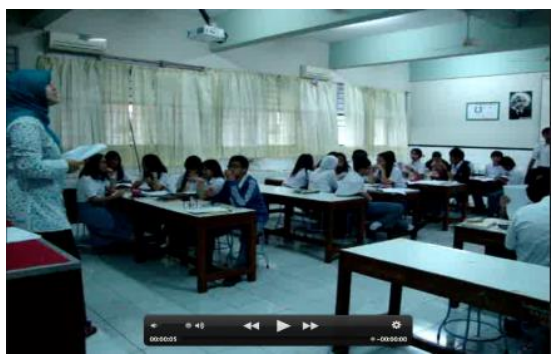

Gambar 4. Tahap Eksplanasi 


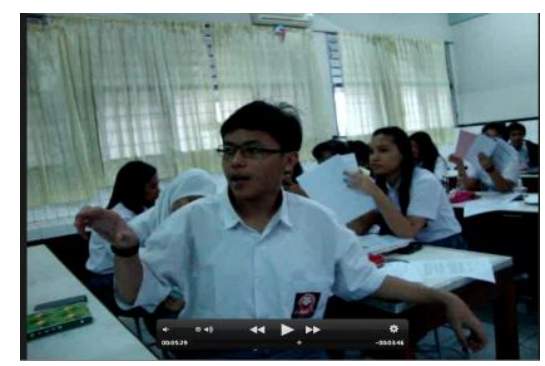

Gambar 5. Tahap Elaborasi

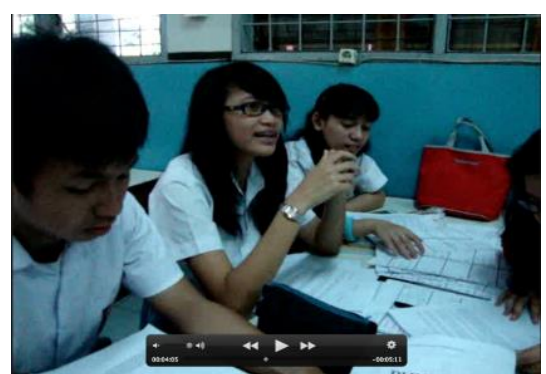

Gambar 6. Tahap Evaluasi

\section{HASIL DAN PEMBAHASAN}

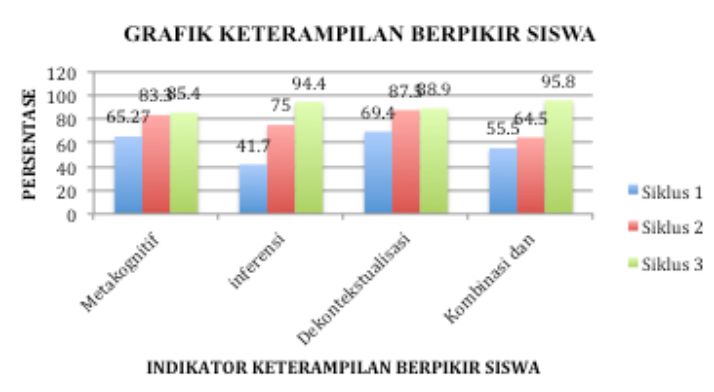

Gambar 7. Grafik Keterampilan Berpikir

Dari hasil penelitian tindakan penerapan model Learning Cycle untuk meningkatkan keterampilan berpikir siswa pada pembelajaran fisika di kelas X SMA Negeri 21 diperoleh hasil-hasil seperti terurai dalam gambar 7.

Pada siklus I, tahapan perencanaan pembelajaran yang dilakukan berdasarkan observasi karakteristik peserta didik yang sebenarnya sangat aktif dalam pembelajaran, tetapi mereka menjadi pasif karena pembelajaran yang lalu tidak melibatkan peserta didik dari awal pembelajaran dimulai, sehingga proses pembelajaran berfokus pada tahap eksplorasi yaitu dengan demonstrasi sederhana.

Dalam tahapan tindakan guru menyiapkan lembar kerja sederhana tentang demonstrasi yang akan dilakukan pada pertemuan bab terakhir bab suhu dan kalor, guru mengelompokkan siswa yang terdiri dari 4 orang, menyiapkan presentasi yang menunjukkan fenomena suhu dan pemuaian dalam kehidupan sehari-hari dan demonstrasi sederhana tentang alat ukur suhu yang tepat, siswa mengungkapkan ide mereka dengan bahasa mereka sendiri tentang ketidaktepatan tangan sebagai alat ukur suhu. Siswa berdiskusi tentang bagaimana definisi suhu ditinjau dari kesetimbangan termal, dan 
terlihat siswa masih ragu-ragu untuk berpartisipasi dalam tanya jawab, guru pun mengambil insiatif langsung dengan memberikan termometer raksa agar siswa bisa menganatomi bagian-bagian termometer, dan memberikan permasalahan bagaimana perbandingan skala celcius dengan skala lainnya seperti Fahrenheit,Reamur,dan Kelvin. Guru tidak lupa memberikan evaluasi di akhir siklus, memberikan jurnal siswa tentang pembelakaran Learning cycle pada akhir siklus.

Pada tahap observasi, proses pembelajaran menggunakan Learning cycle tetapi siswa masih beradaptasi dalam proses engagement. Tahapan dalam pembelajaran dalam model Learning cycle masih dititikberatkan pada engagement dan exploration, dimana siswa masih diperkenalkan dalam model pembelajaran.

Pada tahap Refleksi, menurut hasil observasi siswa belum terbiasa dengan model Learning cycle, keaktifan siswa selama proses pembelajaran masih minim, misalnya siswa harus ditunjuk terlebih dahulu oleh guru untuk maju mengerjakan soal. Dalam pembelajaran siklus I,keterampilan berpikir siswa masih belum terlihat lebih baik dari sebelumnya karena memerlukan adaptasi untuk setiap proses dalam tahapan Learning Cycle. Tingkat pencapaian KKM untuk siklus ini sebesar $81,39 \%$ dengan persentasepencapaian tes keterampilan berpikir siswa siklus 1 masih kurang, untuk kemampuan metakognitif, 65,27\%, kemampuan interferensi 41,7\%, dekontekstualisasi $69,4 \%$, dan kemampuan mengkombinasikan informasi 55,5\%.

Untuk memperbaiki kelemahan yang ada, dibuat perencanaan perbaikan pada siklus berikutnya yaitu: 1) penyajian materi yang akan diberikan diberitahu kepada siswa dengan cara memberi tugas sebelum pertemuan berikutnya berlangsung, 2) membuat tahap-tahap belajar engagement menjadi tanya jawab dengan siswa sehingga siswa akan merasa terlibat dari awal, 3) memberikan reward (point tambahan) kepada siswa yang aktif selama kegiatan pembelajaran, 4) memberikan punishment (pengurangan point) kepada siswa yang tidak kondusif selama proses pembelajaran.

Pada siklus II, untuk tahap perencanaan belajar siklus IImerupakan refleksi dari siklus 1 yaitu: 1) memberikan motivasi kepada siswa agar lebih aktif dan kondusif lagi dalam proses pembelajaran, 2) guru lebih intensif lagi dalam membimbing siswa selama proses pembelajaran, 3) memberikan reward (point plus) pada siswa yang aktif dalam tahapan engagement,4) menyiapkan instrument untuk siklus II, yaitu lembar observasi kegiatan pembelajaran, soal evaluasi akhir siklus, dan jurnal siswa mengenai pembelajaran Learning cycle yang diberikan pada akhir siklus.

Pada tahap tindakan, guru lebih memperhatikan kelompok-kelompoksiswa yang telah dibentuk, karena pada pembelajaran siklus II ini pembelajaran difokuskan pada tahap eksplorasi yang bisa menghabiskan waktu lebih banyak jika guru tidak mengantisipasi sebelumnya. Guru lebih mengarahkan siswa yang mencoba mencari titik lebur suatu zat dengan memasukkan proses explanation di tahapan exploration tersebut. Untuk tahap elaboration dan evaluation berjalan sangat baik, dan keterampilan berpikir siswa sudah mulai meningkat dengan munculnya pertanyaan-pertanyaan tentang suhu zat yang menurun ketika saat itu mereka sedang memanaskan zat tersebut.

Pada tahap observasi, proses pembelajaran menggunakan Learning cycle sudah hampir maksimal, hanya saja siswa masih kurang terampil berpikir, karena terlalu fokus dalam kegiatan eksplorasi.

Pada tahap refleksi, Siswa mulai terbiasa dengan model Learning cycle, siswa sudah mulai kondusif dalam pembelajaran, karena adanya praktikum. Keaktifan siswa dalam proses pembelajaran terurtama pada tahap eksplorasi, dan elaborasi. Reward yang diberikan pada siswa yang aktif dalam pembelajaran terbukti sangat membantu hasil belajar siswa. Tingkat pencapaian KKM untuk siklus ini sebesar 87,19\% dengan persentase pencapaian tes keterampilan berpikir siswa siklus II baik, untuk kemampuan 
metakognitif, 83,30\%, kemampuan inferensi $75 \%$, dekontekstualisasi 87,30\%, dan kemampuan mengkombinasikan informasi $64,50 \%$. Untuk memperbaiki kelemahan yang ada, dibuat perencanaan perbaikan pada siklus berikutnya: 1) pembelajaran harus dibuat menarik,yaitu dengan mencari kasus pengamatan dengan bahan-bahan yang bisa digunakan dalam kehidupan sehari-hari, 2)membuat tahap-tahap belajar tidak hanya engagement yang menjadi tanya jawab dengan siswa sehingga siswa akan merasa terlibat secara keseluruhan 3) memberikan reward (point tambahan) kepada siswa yang aktif selama kegiatan pembelajaran 4) memberikan punishment (pengurangan point) kepada siswa yang tidak kondusif selama proses pembelajaran

Pada siklus III, tahap perencanaan belajar siklus III merupakan refleksi dari siklus II yaitu: 1) memberikan motivasi kepada siswa agar lebih aktif dan kondusif lagi dalam setiap tahapan pembelajaran, 2) lebih intensif lagi dalam membimbing siswa selama proses pembelajaran, 3) memberikan reward (point plus) pada siswa yang aktif dalam tahapan engagement. 4) menyiapkan instrument untuk siklus III, yaitu lembar observasi kegiatan pembelajaran, lembar kerja siswa yang diberikan di pertemuan sebelumnya,soal evaluasi akhir siklus, dan jurnal siswa mengenai pembelajaran Learning Cycle yang diberikan pada akhir siklus, 5) lebih memperhatikan kelompok-kelompoksiswa yang telah dibentuk.

Untuk tahap tindakan guru memastikan semua perlengkapan untuk tahap eksplorasi dan elaborasi sudah disiapkan dengan baik. Guru membentuk kelompok yang didasarkan pada tingkat keaktifan sehingga bisa memupuk keterampilan berpikir satu sama lain. Dalam siklus III, tahap tindakan oleh guru sangat baik karena persiapan yang matang. Guru dan siswa juga sudah terbiasa dengan tahapan dalam Learning Cycle.

Pada tahap observasi, proses pembelajaran menggunakan Learning cyclesedikit berbeda dengan apa yang diamati dalam siklus II, siswa merasa termotivasi karena faktor media pembelajaran yaitu kalium permanganate yang digunakan dalam tahap eksplorasi. Media ini termasuk sangat sederhana, tetapi mampu membuat siswa di sekolah termotivasi untuk mencapai tahap pembelajaran selanjutnya, karena faktor lingkungan yang sangat memotivasi siswa dalam belajar.

Untuk tahap refleksi, siswa sudah mulai kondusif dalam pembelajaran, karena adanya praktikum. Keaktifan siswa dalam proses pembelajaran terutama pada tahap eksplorasi, dan elaborasi. Reward yang diberikan pada siswa yang aktif dalam pembelajaranterbukti sangat membantu hasil belajar siswa. Tingkat pencapaian KKM untuk siklus ini sebesar 90,12\% dengan persentasepencapaian tes keterampilan berpikir siswa siklus 3 sangat baik, untuk kemampuan metakognitif, 85,40\%, kemampuan interferensi $94,40 \%$, dekontekstualisasi $88,90 \%$, dan kemampuan mengkombinasikan informasi $95,80 \%$.

Untuk memperbaiki kelemahan yang ada, dibuat perencanaan perbaikan pada siklus berikutnya, yaitu: 1) pembelajaran harus dibuat menarik, dengan mencari kasus pengamatan dengan bahan-bahan yang bisa digunakan dalam kehidupan sehari-hari, 2) membuat tahap-tahap belajar tidak hanya engagement yang menjadi tanya jawab dengan siswa sehingga siswa akan merasa terlibat secara keseluruhan, 3) memberikan reward (point tambahan) kepada siswa yang aktif selama kegiatan pembelajaran, 4) memberikan punishment (pengurangan point) kepada siswa yang tidak kondusif selama proses pembelajaran.

\section{PENUTUP \\ Simpulan}

Berdasarkan hasil penelitian dan pembahasan maka dapat disimpulkan bahwa keterampilan berpikir siswa dapat ditingkatkan dengan menerapkan model Learning 
cycle. Hal ini terlihat dengan tercapainya indikator keberhasilan penelitian,yaitu: hasil rata-rata nilai belajar siswa sudah memenuhi indikator keberhasilan dengan skor 75 sudah terpenuhi. Siswa yang memiliki nilai diatas KKM sekolah sebanyak 34 siswa atau sebesar 94\%. Respon siswa pada pembelajaran fisika yang menggunakan metode latihan terstruktur berdasarkan angket yang disebarkan memiliki respon yang baik. Presentase siswa yang mempunyai respon positif terhadap Learning cycle sebesar $72 \%$.

\section{Saran}

Untuk meningkatkan penggunaan model learning cycle dapat meningkatkan keterampilan berpikir siswa dalam belajar fisika, maka kelas-kelas lain diharapkan dapat menerapkan model pembelajaran yang sama untuk meningkatkan hasil belajar siswa pada mata pelajaran lain. Meningkatkan implementasi tindakan baru berjalan 3 siklus, maka penelitian diharapkan tetap dilanjutkan untuk mendapat temuan yang signifikan. Pemberian perlakuan dalam model learning cycle dapat dilakukan secara bertahap dengan waktu yang singkat jika murid melakukan persiapan yang baik sebelum pembelajaran dimulai. Penelitian lebih lanjut dapat dilakukan tidak hanya terkait keterampilan berpikir, melainkan hal-hal lainnya seperti kemampuan menganalisis, membuat kesimpulan, dan kemampuan lainnya terkait proses ilmiah.

\section{DAFTAR PUSTAKA}

Abraham. M.R\&Renner, J.W.1986. The Sequences of Learning Cycle Activities in High School Chemistry. Journal of Research in Science Teaching, 3, 121-134.

Arikunto, Suharsimi., Suhardjono, dkk. 2006. Penelitian Tindakan Kelas. Jakarta: PT. Bumi Aksara.

Astra, Setiawan, Hilman, dkk. 2006. Fisika untuk SMA dan MA kelas X.Jakarta: Piranti Darma Kalokatama.

Direktorat Jenderal Manajemen Pendidikan Dasar dan Menengah Direktorat Jenderal Manajemen Pembinaan Sekolah Menengah Atas. 2009. Panduan Penyelenggaraan Program Rintisan SMA Bertaraf Internasional (R-SMA-BI). Edisi 3.

Ekawarna. 2010. Penelitian Tindakan Kelas. Jakarta: Gaung Persada (GP Press). Fisher, Alec. 2007. Critical Thinking: An Introduction. Cambridge University Press. http://www.northerngrid.org/ngflwebsite/hots/introductiontohots/categorisingthinkingskil ls.htm. 03januari2007, pk 11:58

Lorsbach, A.W.2002. The Learning Cycle as a tool for Planning Science Instruction. http://www.coe.ilstu.edu/scienced/orsbacii/257ircy.html

Pujiastuti, Sintya. 2007. Pentingnya Pertanyaan Dalam Proses Pembelajaran. www.tya.wordpress.com, 2 februari 2009, pk. 15.25 WIB.

Sudijono, Anas. 1996. Pengantar Evaluasi Pendidikan. Jakarta: PT Raja Grafindo Persada.

Sudjana. 1986. Teori Belajar. Jakarta: FIP IKIP.

Suhartadi. 2003. Pengembangan Model Pembelajaran Teknik Berbasis " Siklus Belajar" untuk meningkatkan Kompetensi Life-Skill Lulusan SMK Teknologi. Malang: Laporan Penelitian Hibah Bersaing XI/ 1 Perguruan Tinggi Tahun 2003.

Suparno. Paul. 2005. Miskonsepsi dan Perubahan Konsep Pendidikan Fisika. Jakarta: PT.Grasindo.

Wena, Made.2008. Strategi Pembelajaran Inovatif Kontemporer. Jakarta: PT. Bumi Aksara. 